\title{
2. Beth Dean and the Transnational Circulation of Aboriginal Dance Culture: Gender, Authority and C. P. Mountford
}

\author{
Victoria Haskins
}

One of the highlights of the young Queen Elizabeth II's royal tour to Australia in 1954 was the command performance of an excerpt from the ballet Corroboree. Based on Aboriginal dance steps and performed to Australian composer John Antill's 1946 symphonic ballet of the same name, also inspired by Indigenous traditions, the ballet told the story of a young boy's initiation into manhood. The lead role of the boy initiate was played by the choreographer, a dynamic American dancer, Beth Dean, performing in a nylon brown bodystocking and make-up mimicking ochre bodypainting, her hair pulled back in a chignon that suggested the hairstyles of the central desert. A curious spectacle, indeed, as one young English woman watched another young, American woman, play out the initiation to manhood of an Aboriginal youth, as a symbol of Australia's distinctive cultural identity.

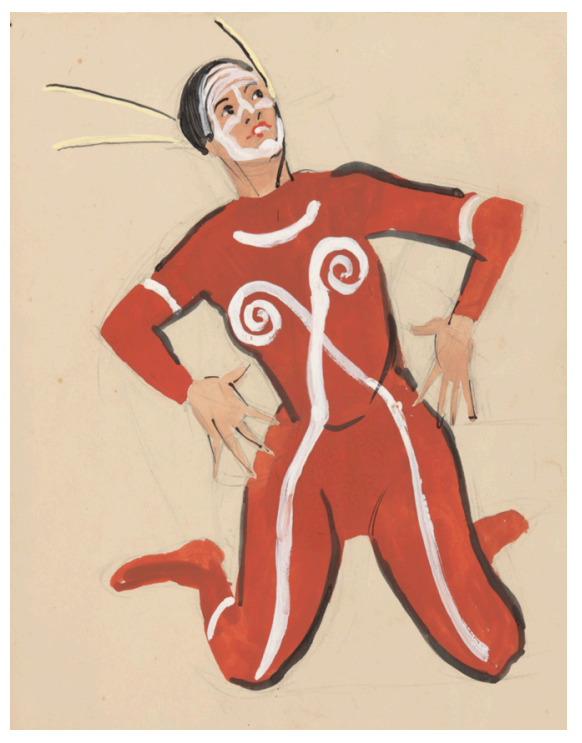

Figure 1: A sketch of Beth Dean in costume for the ballet Corroboree, dated 1950. William Constable, 1906 Bendigo, Victoria-1989 Melbourne, Victoria. Drawing, pencil, ink and goache on cream paper, $31.9 \mathrm{~cm} \mathrm{~h} \times 23.6 \mathrm{~cm} \mathrm{w}$. 
Dean's Corroboree replaced an earlier version choreographed by the Australian choreographer Rex Reid and performed in 1950, in which a medicine man figure had played the lead role. Despite being popular with audiences, Reid's pageantlike ballet, with its mask-wearing dancers, was seen as an inadequate vehicle for showcasing the best of Australia's national culture. In 1951, journalist and travel writer Colin Simpson pronounced the ballet a 'gaudy, circus-like travesty of corroboree', and complained: 'Through lack of understanding and plain lack of knowledge, the choreographer had completely missed the spirit of the real thing. ${ }^{1}$ Approached by Dorothy Helmrich of the Australian Arts Council to rechoreograph the ballet for the Queen's impending visit two years later, Dean's challenge was to succeed where her predecessor had failed.

And she certainly did so. Crucially, Dean made an eight-month-long and very well publicised research trip around central and northern Australia gathering the material she needed to stage a truly 'authentic' Aboriginal ballet. After showing in Sydney for a few weeks, the ballet was then toured for a period of four months around rural New South Wales, both urban and rural audiences receiving it with enthusiasm. Unlike Reid's version, Dean's ballet was also warmly received by the critics. Rapturous reviews praised the ballet's authenticity and Dean's ability to capture Aboriginality. '[F]or me there's a stone-age antiquity in its atmosphere that makes it supremely Australian. With amazing sensitivity Beth Dean has crept inside the skin of our aborigine: she knows his mind, his spirit, his beliefs, his customs and his art of dancing', wrote Eunice Gardner in the Columnist. 'In one grand, sensitive, soul-exposing sweep', the Daily Examiner editorialised, 'Beth Dean, an American shows, as even our best writers have not been able to do, what is basically Australian'. Critics felt Dean had 'crept inside the skin of our aborigine', to present something 'supremely Australian'. ${ }^{2}$ Indeed, enthused one editor, 'Beth Dean, an American shows, as even our best writers have not been able to do, what is basically Australian'. ${ }^{3}$ American Beth Dean has with her fine intellect, taken her brush and obliterated the memory of some awful chichi choreography we have had to put up with', wrote another critic. Corroboree was 'an Australian masterpiece in which a Yank shares'. ${ }^{4}$

\footnotetext{
1 Colin Simpson, Adam in Ochre (Sydney: Angus \& Robertson, Sydney, 1951), quoted in Stephanie Burridge, The Impact of Aboriginal Dance on Twentieth Century Australian Choreography with a Practical and Creative Study (PhD, London Contemporary Dance School at The Place, University of Kent at Canterbury, 1997), 60.

2 Eunice Gardner, Daily Telegraph, 12 February 1954 in 'Reviews cuttings' Beth Dean and Victor Carell Papers, 1880-1920, MLMSS 7804/13, Mitchell Library, NSW (hereafter Dean Papers). Also transcribed in Margaret Abbie Denton, Corroboree/Choreography Beth Dean 1954, MS 9469, National Library of Australia, Canberra, viii-xi.

3 Unattributed, 'Bush Ballet for Britain', Daily Examiner (Grafton), 16 March 1954, Dean Papers MLMSS 7804/13; and Denton Corroboree/Choreography Beth Dean 1954, viii-xi.

4 Transcribed review, Andrea, Mirror, 7 February 1954, held in Denton Corroboree/Choreography Beth Dean 1954, viii-xi.
} 
Beth Dean's Corroboree has garnered attention from numerous scholars over the years, as a particularly iconic moment in the history of the nationalist appropriation of Aboriginal music and dance. ${ }^{5}$ Little, however, has been said about the influence of Charles Pearcy Mountford, despite Dean's insistence that the catalyst for the direction her career would take was a chance encounter with the charismatic anthropologist in a New York hotel room. In a previous study of the transnational nature of Dean's performance and of the ballet itself as a transnational production, I touched briefly upon Mountford's role, ${ }^{6}$ but an extended examination of the dynamic between the anthropologist and Dean and her ballet allows us to consider the gendered nature of the production of knowledge about Aboriginal culture, through cross-cultural exchange. Through her connection with Mountford, Dean obtained her authority and her credentials as one who could produce an 'authentic' version of Aboriginal culture for reworking in the most Westernised dance form, modern ballet. Dean represented the emancipated modern white woman, yet Mountford's role in Dean's performative appropriation of Aboriginality highlights paradoxically that her transgression of race and gender, embodied in her dancing as an Aboriginal youth becoming a man, was ultimately an appropriation of white male authority.

5 Catrina Vignando, 'Corroboree: Aboriginal inspiration in contemporary Australian ballet', Olive Pink Society Bulletin, 3:2 (1991): 10-14; Candice Bruce and Anita Callaway, 'Dancing in the Dark: Black corroboree or white spectacle?', Australian Journal of Art 9 (1991): 79-104; Lyn A. Riddett, “"Be Aboriginal": Settler women artists inspired by Aboriginal artists', Northern Perspective 19:1 (1996): 51-60; Michelle Potter, 'Making Australian Dance: Themes and variations', Voices (1996): 10-20; Amanda Card, 'From “Aboriginal Dance" to Aboriginals Dancing: The appropriation of the "primitive" in Australian dance', in Speaking of History: Dance scholarship in the '90s: Proceedings of Society of Dance Scholars Nineteenth Annual Conference (Minnesota: University of Minnesota, 1996), 115-26; Stephanie Burridge, The Impact of Aboriginal Dance on Twentieth Century Australian Choreography with a Practical and Creative Study (PhD, London Contemporary Dance School at The Place, University of Kent at Canterbury, 1997); Amanda Card, 'From "Aboriginal Dance" to Aboriginals Dancing: The appropriation of the "primitive" in Australian dance, 1950 to 1963', in Heritage and Heresy: Green Mill Papers 1997 (Canberra: Australian Dance Council, 1998), 40-6; Jan Kociumbas, 'Performances: Indigenisation and postcolonial culture', in Cultural History in Australia, eds Hsu-Ming Teo and Richard White (Sydney: UNSW Press, 2003), 127-41; Amanda Card and Carole Y. Johnson, 'Aboriginal Influences', in Currency Companion to Music and Dance in Australia, eds John Whiteoak and Aline ScottMaxwell (Sydney: Currency House, 2003); 20-3; Anna Haebich, 'Assimilation and Hybrid Art: Reflections on the politics of Aboriginal art', in The Art of Politics The Politics of Art: The place of contemporary Indigenous art, ed. Fiona Foley (Southport: Keeaira Press, 2006); Victoria Haskins, 'Dancing in the Dust: A gendered history of indigenising Australian cultural identity', in Intersections: Gender, race and ethnicity in Australasian studies, eds Margaret Allen and R K Dhawan (New Delhi: Prestige, 2007), 55-75; Anna Haebich and Jodie Taylor, 'Modern Primitives Leaping and Stomping the Earth: From ballet to bush doofs', Aboriginal History 31 (2007): 63-84; Anna Haebich, Spinning the Dream: Assimilation in Australia 1950-1970 (Fremantle: Fremantle Press, 2008), 320-36; Victoria Haskins, 'To Touch the Infinity of a Far Horizon: A transnational history of transcultural appropriation in Beth Dean's Corroboree 1954', Australasian Drama Studies 59 (2011): 23-38.

6 Haskins, 'To Touch the Infinity of the Far Horizon', 29. 


\section{Meeting Mountford}

Following the production of the ballet, Beth Dean and her Australian-born husband and collaborator Victor Carell published an account of their research travels under the title Dust for the Dancers. In the book's introduction, they explained that as newly wed performers out of work in New York in 1946, they initially conceived the idea of running a radio program on Australian music. (They had heard an NBC radio program introducing South African folk songs that year.) The couple then sought advice from Charles Buttrose, an Australian journalist working in the newly established Australian News and Information Bureau in New York, on acquiring 'background on aboriginal legends' that might be turned into songs or stories for the planned program, 'Song Stories from Down Under'. Buttrose put them in touch with his friend and fellow South Australian, Mountford:

... we met a lean, scholarly gentleman who, his eyes lit with enthusiasm, kept us fascinated for three days (in a tiny hotel bedroom) listening to his tales of the Australian aborigines ... There, in that crowded New York room, our imaginations were so fired that they were able to leap out over the surrounding skyscrapers ... over the vast modern country and the ocean beyond ... past Sydney's golden beaches, to light in the centre of a continent where, surrounded by empty silence, an old man, with bearded face and jutting eyebrows, sat chanting. Out of his strange medley of sounds came stories of great spirit heroes wandering through the world when it was young, creating the rivers and making the mountains. The shadows about him were peopled with leaping, virile young men, their dark glistening bodies ochred-daubed and decorated in fantastic designs.

... After Charles Mountford had returned to Australia, the vision he kindled remained with us. ${ }^{7}$

Positioning Mountford in such a place of dominance-the book's opening pages - was clearly a device to assert the credibility and authority of their research from the outset. The book did not come until after the ballet had toured, but even before the ballet opened, Mountford's influence and support had been emphasised in the publicity and promotion. It was, reported People magazine in 1953, her meeting with the anthropologist that first brought Dean to the realisation 'that in the hinterland of Australia was a rich and hitherto untapped source of inspiration for the creative artist in dance', and more importantly, it was the inspiration for her to look for an opportunity to come to Australia to learn all about Aboriginal dance, and 'perhaps, later, make ethnic dancing her

7 Beth Dean and Victor Carell, Dust for the Dancers (Sydney: Ure Smith, 1955), 1-2. 
speciality' ${ }^{8}$ Corroboree did indeed make Dean's career, transforming her from a little-known musical dancer and choreographer on American entertainment circuits to a renowned international expert on Indigenous dance. ${ }^{9}$

Dean's narrative of her meeting with Mountford, reiterated over the years in various interviews, conforms to an older tradition of women performers' memoirs: a crucial encounter with a powerful man that provided the catalyst for the performer's success being a device which removed agency from the female performer. ${ }^{10}$ But what is striking in this construction is the way that it operated to negate not so much Dean's own agency in shaping the direction her career took, but in erasing the broader context in which Corroboree was created as a transnational product circulated by women.

\section{White Women and Corroboree}

Although Dean never referred to or mentioned any of her predecessors, there was an established, if contested, tradition of white women interpreting or mediating Indigenous dance performance in Australia for white audiences. Public descriptions of corroborees were dominated by white men's voices throughout the colonial period. In that time we find only a few surviving traces of a white female view in the private letters of women allied to the most wealthy and powerful of white men, such as Elizabeth Macarthur, ${ }^{11}$ or, at the other end of the colonial century, Queensland pastoralist's wife Jane Bardsley (who boasted that she could 'certainly corroboree as well as any gin'). ${ }^{12}$ Women's public claims to knowledge were dismissed out of hand. Thus an early colonial

8 Unattributed, 'From Primitive to Ballet', People, 12 August 1953, 17-20: Dean Papers ML MSS 7804/24.

9 She and Carell remained in Australia after the ballet ended, and her next work was a ballet for television, G'Day Digger, created around 1956, followed by Dreaming Time Legends in 1965, another made for television production which consisted of two ballets based on Aboriginal legends from New South Wales. Dean was invited to participate in Mexico's 1968 Cultural Olympics (where she taught Indigenous dance and arranged for another Aboriginal-themed ballet, Kukaitcha, to be performed), but her focus was shifting to the South Pacific. In 1970 she established the Cook Islands National Arts Theatre; she also assisted in the organisation of the first South Pacific Festival of Arts in Suva in 1973, and directed performances for the opening of the Sydney Opera House the same year. Over the years Dean also published numbers of articles and books, some with her husband, about ballet and Indigenous dance. She passed away in 2012 and was the subject of an obituary in the Sydney Morning Herald: Unattributed biography, 'Dean, Beth (1918-2012)', Australia Dancing, accessed 14 March 2012, http://www.australiadancing.org/subjects/26.html; Don Niles, personal communication to ICTM Oceania Study Group, 22 February 2012, ictm-oceania-1@lists.hawaii.edu; Valerie Lawson, 'Dancer Many Steps Ahead of Her Time: Beth Dean Carell 1918-2012,' Sydney Morning Herald, 12 May 2012.

10 See Lena Hammergren, 'Many Sources, Many Voices', in Rethinking Dance History: A reader, ed. Alexandra Carter (London: Routledge, 2004), 26

11 Cited in Candice Bruce and Anita Callaway, 'Wild Nights and Savage Festivities: White views of corroborees', Art and Australia 27:2 (1989): 275.

12 Letter, Jane Bardsley Atherton, dated October 1898, in Jane Bardsley's Outback Letterbook, Across the Years 1896-1936, ed. John Atherton Young (Sydney: Angus \& Robertson, 1987), 107-10. 
painting of an Aboriginal (male) dance scene by a woman, Sydney merchant's wife Sophia Campbell, bore the blunt notation by her niece's husband: 'NB this Corrobery has no business here as it is never danced in the day-time.' Such was the male conceit of the authoritative eye that the panorama was, until recently, wrongly attributed to this man. ${ }^{13}$ The female view was also constrained by the prescriptions of class and gender. As colonial historian of manners Penny Russell has pointed out, the 'colonial lady' demonstrated her moral virtue and rank by 'enactments of social blindness' and 'undisturbed comportment' when confronted by 'savage' male sexuality. While white male accounts could and did freely assert the 'most lewd and disgusting character' of Aboriginal 'corrobbories', 14 white women did not see and certainly did not comment publicly on Aboriginal men or their masculinity. ${ }^{15}$

By the end of the nineteenth century, however, such women - squatters' wives such as Kate Langloh-Parker, or her predecessor, Mary A. Fitzgerald-began to find currency in re-telling 'authentic legends' of Aboriginal people for white readers, referring to Aboriginal men as their sources. ${ }^{16}$ In the twentieth century, the Durack sisters, Elizabeth and Mary, daughters of a pastoral dynasty of farnorth-western Australia, would achieve recognition for these accounts. ${ }^{17}$ Even so they could not always be counted on to bring the writer commercial successas Mary Grant Bruce discovered in 1922. ${ }^{18}$ Rather, the irrepressible spate of Aboriginal legends by white women from the turn of the century reflected an impulse based upon the changing performativity of white womanhood. The production of this cross-cultural knowledge must be seen in the broader context of an emergent feminist movement in which the sanctity of white motherhood was argued, ${ }^{19}$ hand-in-hand with the construction of an exemplary white female pioneering past, as embodied in the figure of the mythic 'good fella missus' who cared for Aboriginal people. ${ }^{20}$

13 Caroline Jordan, Picturesque Pursuits: Colonial women artists and the amateur tradition (Melbourne: Melbourne University Press, Melbourne, 2005), 58-9.

14 Alfred Giles 1887, quoted in C. D. Rowley, The Destruction of Aboriginal Society (Ringwood: Penguin, 1986), 214.

15 Penny Russell, 'Cultures of Distinction', in Cultural History in Australia, eds Hsu-Ming Teo and Richard White (Sydney: UNSW Press, 2003), 170.

16 K. Langloh Parker, Australian Legendary Tales (Middlesex: Tiger Books, 1998); Mary A Fitzgerald, King Bungaree's Pyalla and Stories Illustrative of Manners and Customs that Prevailed Among Australian Aborigines (Sydney: William Brooks \& Co, 1891), ii.

17 Mary and Elizabeth Durack, All-About: The story of a black community on Argyle Station, Kimberley (Sydney: The Bulletin, 1935). See Brenda Niall, True North: The story of Mary and Elizabeth Durack (Melbourne: Text Publishing, 2012), 38-9.

18 The research that went into Bruce's The Stone Axe of Burkamukk 'cost her more time and effort than any of her [Billabong] novels, but it sold poorly. Evidently her public preferred her to keep to fiction, and had little interest in a sympathetic attempt to study black civilization in Australia.' Brenda Niall, Seven Little Billabongs: The world of Ethel Turner and Mary Grant Bruce (Melbourne: Melbourne University Press, 1979), 166.

19 Marilyn Lake, 'Feminist History as National History: Writing the political history of women', Australian Historical Studies 27:106 (1996): 158.

20 Madeline E. McGuire, 'The Legend of the Good Fella Missus', Aboriginal History 14:2 (1990): 143. 
The appearance of female public commentators on Aboriginal culture at this time was a reflection of the same forces. In the newly opened regions of central Australia during the 1920s and 1930s, white women such as the missionary Annie Lock, the anthropologist Olive Pink, and, most famous of all, the journalistanthropologist Daisy Bates, found opportunities to claim a public voice. These women not only provided firsthand accounts of 'corroborees' but even asserted a directing role in their performance. In 1920, for instance, Bates was asked to arrange an Aboriginal performance for the Prince of Wales on tour in Australia, and shared the dais with him as she explained the significance of the Aboriginal dances. ${ }^{21}$ In 1934, she was prevailed upon again, to arrange the performance of 'tribal dances' at Ooldea for the visit of his son, the Duke of Gloucester; Bates described how despite their 'reluctance' to perform their secret initiation ceremonies for outsiders, the 'natives ... promised me' they would 'give a little of this amazingly agile dance'. 'Their confidence and trust in me was fully illustrated in their own way when they gave me charge of their young boy novices, whom they took me to see, and touch, and feed', she boasted.

That journey in itself would have made an interesting camera picture. There were no native women present, only 25 men, all blood relations of the boys, and myself, walking quickly in single file through the tangled bush, and later the ceremony of approach, \&c., to the young lads. ${ }^{22}$

This newfound opening for white women generated a certain degree of competition. While Bates was planning her performances, Annie Lock arranged a rival performance for the Duke at Ooldea - declaring that the Prince of Wales had been 'terribly disappointed' by Bates' display in 1920 - and she wanted to show his son the Duke 'that they [the Aborigines] are better cared for now the mission has taken them up' ${ }^{23}$ Lock 'had the honor [sic] of setting the corroboree going, and they had conferred upon her some native honours' ${ }^{24}$ in a performance notable for the 'attractive' dark blue shorts worn by the dancers. ${ }^{25}$

At the same time Aboriginal people themselves were being prevented from performing corroborees, whether by missionaries or frontier violence in remoter regions, or by an increasingly draconian administration in the 'settled' states. In 1926, the offer of another white woman, Elizabeth McKenzie-Hatton of the Australian Aboriginal Progressive Association (AAPA, an Aboriginal

\footnotetext{
21 Jim Anderson, “'A glorious thing is to live in a tent in the infinite": Daisy Bates', in Uncommon Ground: White women in Aboriginal history, eds Anna Cole, Victoria Haskins and Fiona Paisley (Canberra: Aboriginal Studies Press, 2005), 221-2.

22 'Wild Natives to Greet Duke', The Advertiser, 8 October 1934.

23 Lock to Sexton, 5 September 1934, Aborigines Friends Association Correspondence Files, SRG 139/1/324, State Library of South Australia (SLSA), Adelaide.

24 Report of visit to Ooldea, 25-27 September 1934, Sexton to Hudd (Public Works Commissioner), 4 October 1934, Aborigines Friends Association Correspondence Files, SRG 139/1/337, SLSA.

25 'Demonstration by Natives Under Miss Lock', The Advertiser, 12 October 1924.
} 
political organisation based in NSW), to organise a performance by the AAPA's 'corroboree group' for the visit of the Duke and Duchess of York was politely but firmly declined. ${ }^{26}$ When it came to expressing their opinion of appropriations of corroboree, Aboriginal people were at a great disadvantage, and their voices are few in the record. A rare insight is provided by a 1922 letter to the editor of the Sydney Morning Herald from Annie Bowden, an Aboriginal woman at La Perouse, Sydney (and an AAPA member), in response to one of Bates' very early sensational articles. Bowden took issue with many of Bates' statements about Aboriginal culture and her descriptions of initiation ceremonies, challenging Bates' claim to be an authority on this subject in particular:

As for the awful practices carried out at initiations, just let me say this: If, as Mrs Bates says, they were such cannibals there, and they killed and ate people for the smallest offence, how is it she was allowed to witness so dreadful a scene, without being eaten herself?

'Initiation as I know it was a sacred rite', she continued, 'and no one but a select few were ever allowed to witness it ... so how Mrs Bates comes to know so much about initiation I cannot tell.'27 By the 1930s the surge of white interest in the new 'social anthropology' was seen by Aboriginal activists as a retrograde step away from the equality 'earned' during the First World War, as a way in which white Australians gave themselves 'the pleasure of feeling superior', and diametrically opposed to the demand for equal rights and opportunities. ${ }^{28}$

And yet performing 'corroboree' continued to provide an opportunity for white women to voice authority and knowledge. In 1933, musician and lyricist Varney Monk created a 'corroboree' piece for the musical Collits Inn (billed as 'the first Australian historical musical play'), ${ }^{29}$ as a way of providing 'the background

\footnotetext{
26 E. McKenzie-Hatton to Governor-General, 5 November 1926; Major-General, Commonwealth Director, to E. McKenzie-Hatton, 3 December 1926, A6680/1 DY25/19, National Archives of Australia (NAA), Canberra. My thanks to John Maynard for bringing my attention to this episode and documentation. See also John Maynard, 'Light in the Darkness: Elizabeth McKenzie-Hatton', in Uncommon Ground: White women in Aboriginal history, eds Anna Cole, Victoria Haskins and Fiona Paisley (Canberra: Aboriginal Studies Press, 2005).

27 'Vanishing Aboriginals', Annie Bowden letter to the editor, Sydney Morning Herald, 20 May 1922. Thanks to John Maynard for drawing my attention to this source, also.

28 J. T. Patten and W. Ferguson, Aborigines Claim Citizen Rights! (Sydney: The Publicist, 1938), 6, 11 (the manifesto of the Australian Aborigines Progressive Association). Similar views were expressed by the leader of the Victorian Aboriginal political group, the Australian Aborigines League. See Cooper to Minister for the Interior (Cmwlth), 15 June 1936, CRS A659, 1940/1/858, NAA: 'The [Australian Aborigines'] League does desire the preservation of the best features of aboriginal culture and feels that the preservation of certain corroboree dances, in the way the old World peoples have retained their folk dances, is in harmony with this ... [but] great care should be exercised till such time as the native race is so fully civilised that the outlook on the corroboree is just that of the Old World civilisation on their folk dances.' Cited in Russell McGregor, Imagined Destinies: Aboriginal Australians and the doomed race theory, 1880-1939, (Victoria: Melbourne University Press, 1997), 250-1.

29 John Thomson, 'It's Australian - and it's good!' National Library of Australia News, 14:3 (2003), accessed 8 June 2014, http://www.australianmusicals.com/article_itsaustralian.htm.
} 
touch of reality of the period'. She claimed she had adapted it from a song she had learned from an Aboriginal 'Queen' Rosie, 'the last full-blooded aborigine of the Illawarra tribe', ${ }^{30}$ who had danced and sung for Monk's edification. ${ }^{31}$ The inclusion of a 'Corroboree Dance' in the performance probably marks the first known attempt to adapt Aboriginal dance to ballet - 'Something for even New York to get excited about', in the words of one reviewer-though we know little about the actual performers, or the choreography. ${ }^{32}$ Possibly the first white woman in recorded history to offer a public performance of corroboree herself was the writer Zora Cross, who performed her 'Aboriginal Corroboree' on 5 November 1937, before the Society of Arts and Crafts of New South Wales. ${ }^{33}$

Despite the prominence of women in the cross-cultural re-production of Aboriginal dance and music, it would be a man who would ensure that such an enterprise was taken seriously. In 1946, composer John Antill created the score for which both Reid's and Dean's later ballets would be choreographed, based on his childhood memories of watching tourist corroborees at La Perouse Aboriginal reserve. The score, which he called 'Corroboree', was to be hailed as the first truly Australian piece of contemporary music. ${ }^{34}$

Antill's achievement marked the beginnings of an incorporation of Aboriginal dance into elite culture, hand in hand with the development of modern dance and its interest in 'the primitive' in the wider western world, that would finally register internationally. The following year, Ted Shawn, a leading US exponent of modern dance, came to Australia to learn about Aboriginal dance. Shawn (who co-founded the Denishawn School of Dance with his wife, 'one of America's most famous women dancers, Ruth St Denis') was self-consciously masculinist in his outlook. He had, he wrote in his 1953 account of his travels (published just as Dean and Carell were carrying out their own research in central and northern Australia), begun to feel 'that dancing in western countries had lost some of its vitality through the preponderance of women dancers'.

This had given the lead to the ballerina, whereas in primitive countries men were the main performers. It was the fact that Australian corroboree was performed almost exclusively by men that made him so anxious to see it. ${ }^{35}$

\footnotetext{
30 Letters (n.d.) from Varney Monk (1892-1967), quoted in J. West, ed. Collits' Inn: A romantic Australian operetta by T Stuart Gurr with lyrics and music by Varney Monk (Sydney: Currency Press, 1990), xii.

31 M. H. W., 'Queen Rosie's Requiem,' Sydney Morning Herald, 21 June 1932.

32 Robyn Holmes, 'Australian Music Editing and Authenticity: "Would the real Mrs Monk please stand up?"', in The Editorial Gaze: Mediating texts in literature and the arts, eds Paul Eggert and Margaret Sankey (Oxon: Routledge, 2013), 221.

33 Glenn R. Cooke, 'Aboriginal Motifs in the Decorative Arts, "an art for Australia from Australians"', in Motif and Meaning: Aboriginal influences in Australian art 1930-1970, ed. Claire Baddley (Ballarat: Ballarat Fine Art Gallery, 1999), 15.

34 Vignando, 'Corroboree', 11.

35 John K. Ewers, With the Sun on My Back (Sydney: Angus \& Robertson, 1953), 26-7.
} 
Meanwhile, Charles Mountford was rising to international prominence. Having established a national profile for his writings on Aboriginal art and culture during the 1930s, he had been sent to New York at the end of 1944 by the Australian government to promote Australia, by conducting a lecture series on Australian and Aboriginal culture. ${ }^{36}$ Mountford's popular lectures by and large focused upon Aboriginal men. In New York he had with him a number of ethnographic films and recordings he had produced, including the documentary Tjurunga (1946) about his 1942 expedition to the MacDonnell Ranges and the art of sacred objects there; a film about the celebrated artist Albert Namatjira; and a film of circumcision and sub-incision rituals. Like Shawn's determination to study Aboriginal male dancers, the attention to male activities - particularly, we might argue, male rituals around circumcision-reflected a broader phallocentrism within the popular ethnographies of the postwar period. The doings of men were considered of significance and interest to all; Aboriginal women's culture was deemed of interest only to women, and marginalised. As social anthropology became an established discipline, female students and scholars were dissuaded from conducting research on Aboriginal men, although the professors were happy to teach contingents of admiring women about Aboriginal men. ${ }^{37}$ Showing his circumcision film to mixed audiences of men and women, Mountford noted that the women 'showed as much interest in the matter as did the men, but did not ask any questions'.$^{38}$ Given the anxieties about women's roles in the 1950s, it is somewhat ironic that white women should now assert their interest in 'knowing' Aboriginal men. But after the war, urban, middle-class, mobile and modern white women quickly discovered a new power to flex, both as consumers, and as knowledge-producers in their own right. It was at this point in the trajectory that Beth Dean met Mountford and began to live out her dream to 'tell the world of the Aboriginal culture' ${ }^{39}$

\section{Mountford in New York}

Despite being somewhat estranged from the academic anthropological establishment, Mountford's impact on the transnational circularisation and popularisation of a particular discursive representation of Aboriginality in the 1940s, and particularly the 1950s, was profound. His connections with Dean's ballet might be traced back even to Simpson's much-quoted criticism of her

\footnotetext{
36 Walter W. Stone, ed., Charles Pearcy Mountford: An annotated bibliography (Cremorne: The Stone Copying Company, 1958), 61.

37 See Francesca Merlan, 'Gender in Aboriginal Social Life: A review', in Social Anthropology and Australian Aboriginal Studies, eds R. M. Berndt and R. Tonkinson (Canberra: Australian Institute of Aboriginal Studies, 1988), 19-45.

38 C. P. Mountford 'A Journey to America 1945-6', Vol. 4, Mountford-Sheard Collection, PRG 1218/16/4, State Library of South Australia, Adelaide, 6 April 1945.

39 Beth Dean to Mr Green, 27 September 1951, Dean Papers MLMSS 7804/3.
} 
predecessor Reid - Simpson had made his scathing remarks in the 1951 book he published based on his association with Mountford's 1948 expedition (the American-Australian Scientific Expedition to Arnhem Land), Adam in Ochre, the book which propelled Simpson's own transnational career, 'from journalist to globetrotting writer of travel books' ${ }^{40}$

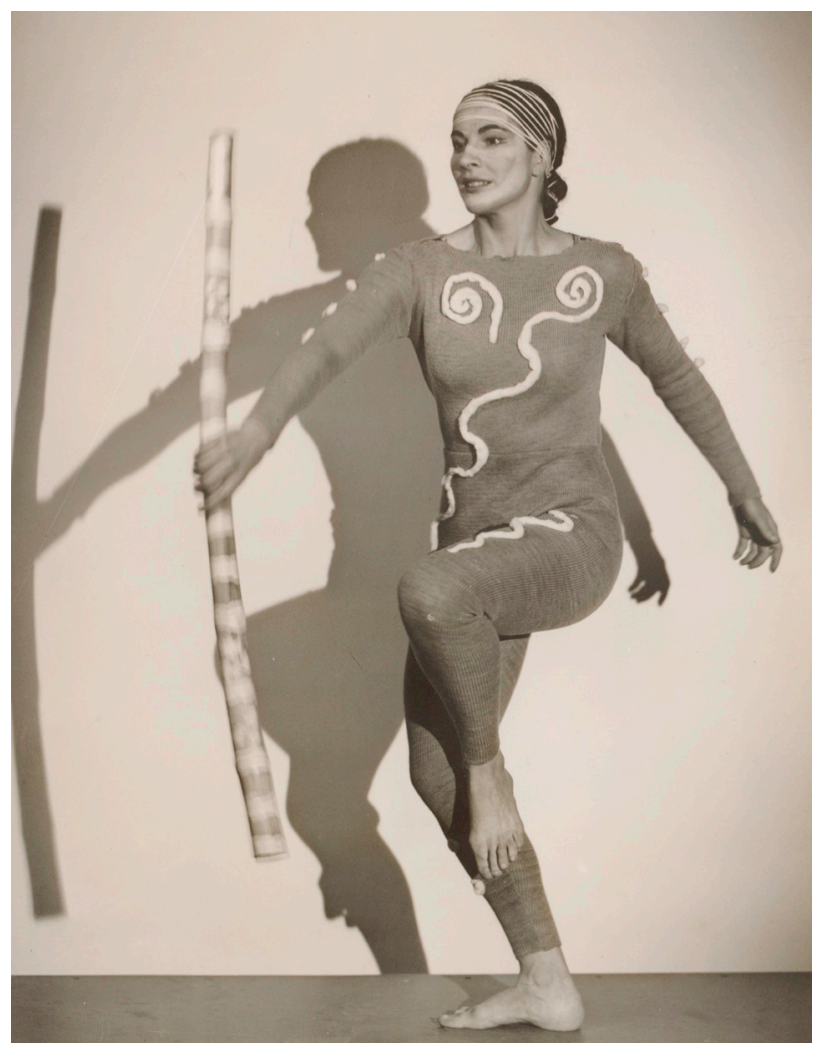

Figure 2: Beth Dean as the Initiate, Corroboree, dated 1949.

Source: Photographer unknown. Royce Rees collection, State Library of NSW (PXA 739/1867).

In Dean's own account, it was not until after the couple returned from their first visit to Australia in the early 1950s that she first contemplated creating a balletic 'corroboree' to accompany Antill's 1946 composition. In fact she denied having ever seen Rex Reid's version (rather surprisingly, given that the couple would be in Australia during the entire year of 1950, when Reid's ballet was performed). ${ }^{41}$

40 See Martin Thomas, 'A Short History of the 1948 Arnhem Land Expedition,' Aboriginal History 34 (2010): 154.

41 Copy, Dean to Peggy van Praagh, 20 April 1962, Dean Papers MLMSS 7804/4. It is also curious that both the sketches of her in costume drawn by William Constable and held in the National Museum were dated 1950, and the photograph of her held in the Mitchell Library, in Sydney, was dated 1949, although these dates 
Instead she claimed that the idea first came to her when she and her husband heard Antill's symphonic ballet being played on the radio in Canada, where they were holidaying with friends. According to the story, Carell said to Dean at the time, 'You're going to do that ballet someday'. Dean replied, 'Oh, you're teasing, that couldn't be so'. 'No', he said, 'I think that's a good idea'. ${ }^{42}$

Nevertheless it is evident from Mountford's personal papers that Dean and her husband had already thought about developing an Aboriginal-inspired ballet by the time they approached him in New York in March 1945 (not, as they claimed, in 1946). Mountford's diaries record that he had gone to Radio City, an entertainment venue, where he found 'a young chap and his wife' talking to his friend Buttrose about Australian music. As they were 'really after aboriginal music', Buttrose referred them to him; the couple were looking for some recorded music but Buttrose had been able to provide them only with one song, 'rewritten by an Australian, who, although he may have retained the notes certainly had not retained the rhythmic pattern'. So Mountford arranged to meet them the following day at the New York Public Library, to show them a paper on Aboriginal music by Professor E. Harold Davies, an eminent Australian authority on Aboriginal music at that time. When the couple saw this paper, Mountford recorded with satisfaction, 'they realized how far out the other chap was'. The anthropologist then took them to the American Museum of Natural History and played them the recordings they 'badly wanted' to hear, his recordings of Adnyamathanha songs from the Flinders Ranges region of South Australia. After a lunch together, they went to his hotel room, and it was here that Dean and Carell first aired the idea of 'designing the music and choreography for a ballet' based on Aboriginal dance. ${ }^{43}$

Mountford had, somewhat cautiously, supported the idea. 'I personally think it could be done', he mused, 'but the professional ballet dancer would have to unhook his mind from many of the traditional steps and poses'.

Then, that might not attract the crowd and make money, the be-all and end-all of entertainment. Still, the're [sic] keen, and it won't hurt to talk about it. I feel sure that some of the dances I have seen, ie, the simpler ones, would make wonderful ballets, especially if they were performed by artists that know the background.

must be incorrect, as she did not receive the commission to work on the ballet until 1952.

42 Beth Dean, 'Oral History Interview with Hazel De Berg', 4 December 1975, Transcript, in Hazel de Berg collection, DebB 902, National Library of Australia, Canberra (hereafter De Berg Interview).

43 Mountford Diaries, Vol. 3, 22 March 1945, 23 March 1945. 
We had a very happy time, these two young folk and I. They did not leave until 4.30, and that was about 4 hours later than they meant to stay $\ldots{ }^{44}$

Mountford did not seem to take Dean and Carell particularly seriously. He was encountering all sorts of different women who were interested in learning about Indigenous cultures and had ideas about studying and promoting the same for public audiences. There was, for instance, a Bathie Stewart from New Zealand, who gave lectures on the 'Legends of Maori Land', at the Waldorf Astoria in January 1945..$^{45}$ Around the same time that he met the Carells, Mountford promised to visit a Miss Laura Bolton in New York, employed by the Canadian government to record the 'folk music' of that country, 'who had done a great deal of recording of primitive music'. He was a guest at a dinner hosted by the sculptor Malvina Hoffman, who was 'very interested in people, especially primitives'; she told him that in the late 1930s she had organised a 'series of international dances' including those of 'American Indian tribes, Negroes, Haitians, Russians, Polynesians, etc' at Radio City under a program called Dance International, before the whole thing abruptly 'fell to bits' with the onset of the war. 'But they were on the verge of starting something really good, something which Miss Hoffman thought would have lasted', recorded Mountford ${ }^{46} \mathrm{He}$ also recorded a conversation he'd had with an American woman, a Mrs Oghtwaite, 'really a delightful person', who told him forthrightly that it was 'the dancer, the artist, the musician', and not the anthropologist, who should be investigating Aboriginal cultural life, and Mountford amiably agreed.$^{47}$ Just the month before meeting with the Carells, a leading and influential English ballet critic, Arnold Haskell, had written to Mountford suggesting that if he could do 'an illustrated lecture on aboriginal dancing, [he knew] many ladies that would welcome it', and could 'fix up' some appearances for him in London. ${ }^{48}$

While Mountford capitalised on women's fascination with his subject, such curiosity and interest could quickly turn to competition. His customary equanimity was shaken when he encountered expatriate Australian Winifred Walker (just two weeks after meeting Dean) showing Australian films under the billing 'Lecturer, Photographer, World Traveller'. Walker had, 'by all the bad luck in the world', managed to procure a copy of his film Tjurunga, from a 'Yankee' woman who'd bought it in Australia. Walker promised not 'to show it in any place where [he was] likely to appear'. She was, to his relief, 'ever such a

\footnotetext{
4 ibid.

45 Flier, Bathie Stewart, n.d, pasted in Mountford Diaries, Vol. 1, 12 January 1945.

46 Mountford Diaries, Vol. 3, 9 March 1945; Vol. 4, 11 April 1945, 13 April 1945.

47 Mountford Diaries, Vol. 3, 9 March 1945.

48 Letter, Haskell to Mountford, 8 February [1945] enclosed Mountford Diaries, Vol. 2.
} 
nice friendly person, a bit of a go-getter, but not to the extent of being greedy' ${ }^{49}$ Dean, for her part, seems to have been cautious not to represent herself as a threat or rival to Mountford.

\section{Dean in Australia}

In 1947, the Carells had their opportunity to come to Australia, as part of the cast for the hit musical Annie Get Your Gun. The show proved to be as popular in Australia as it was in the US, running for three years, during which time Dean (cast in an undemanding support role) had undertaken to learn all she could about Māori and Aboriginal dance, in order to reinvent herself as an 'ethnic dancer'. (The latter she learned largely from Mountford's films, as well as the published works of T. G. H. Strehlow and A. P. Elkin.) At the conclusion of the Annie tour in 1950, Dean gave her first concert performance of Aboriginal dance at the Sydney Conservatorium, then embarked on a tour of country towns in NSW performing Aboriginal and other ethnic dance, under the auspices of the NSW Council of Adult Education. ${ }^{50}$ Leaving Australia the following year, the Carells went to England, where Dean's performance of Aboriginal dance in London's Rambert Theatre was reviewed favourably by none other than Arnold Haskell. Dean recorded that his review 'caused quite a lot of publicity and furore because no one had seen Australian Aboriginal dance before' ${ }^{51}$ It is likely that Mountford facilitated this important connection: 'through her we see for the first time the stone age dance of the aboriginal', Haskell had written, 'vouched for in its authenticity by no less an authority than C. P. Mountford, anthropologist and artist'. ${ }^{52}$ The couple then returned to New York where Dean ran a program titled 'Dance Around the World', at the Museum of Natural History, based upon the material she had developed for her NSW tours. In an array of costumes she performed a range of exotic characters, a particular highlight being a scene from 'an Australian Aboriginal sacred Inkura ceremony of Initiation'. ${ }^{53}$ Performing together-Dean dancing and Carell accompanying her on improvised instruments - they then toured the States, finally ending up in Los Angeles. ${ }^{54}$

From the US now, Dean began to make strenuous efforts to raise funds for a return trip to Australia, to carry out a project researching Aboriginal dance. In the first instance she approached Strehlow for advice and support. Strehlow's

49 Mountford Diaries, Vol. 4, 6 April 1945; Vol. 3, 21 March 1945.

50 'Fred' to Dean and Carell, 16 May 1950, Dean Papers ML MSS 7804/4; and unattributed, 'From Primitive

to Ballet', People, 12 August 1953, 17-20, Dean Papers ML MSS 7804/24.

51 De Berg Interview.

52 'Beth Dean: A note by Arnold Haskell', undated transcription, c. 1951, Dean Papers ML MSS 7804/22.

53 Program, The Center YMHA, 2 November 1951, Dean Papers ML MSS 7804/41.

54 De Berg Interview. 
work was her source for the 'Inkura' ceremony of male initiation, but it is hard to imagine him approving of her enterprise. The powerful anthropologist was not inclined to endorse white women to the study of Aboriginal customs, as he had shown in his attitude to the anthropologist Olive Pink in the late 1930s. At that time he had advised the authorities to deny Pink a permit to go onto the reserves for her research, on the grounds that she had an inappropriate 'habit of interviewing the old men of the tribe' for information on 'the things that may not be told to a woman'. ${ }^{55}$ As Pink had been outspoken on the white sexual abuse of Aboriginal women, Strehlow said she had an 'unhealthy obsession' with sex, and took delight in informing her that her permit to study the Aboriginal people had been denied..$^{56}$

Strehlow's biographer notes that his main motive in blocking Pink was 'territorial' ${ }^{57}$ In Dean's case, however, he seems to have been supportive, advising Dean to approach the head of the Commonwealth Department of Native Affairs, Paul Hasluck, for permission to visit the Aboriginal people of the Northern Territory. ${ }^{58}$ She immediately drafted a letter to Hasluck on the back of Strehlow's communication, dropping Strehlow's name as well as those of Mountford and Professor Elkin, and stressing her 'especial interest in collecting women's ceremonies ... This aspect of ABO [sic] life has never been tabulated' ${ }^{59}$ Perhaps Strehlow had mellowed since his encounters with Pink, but more likely Dean's care not to challenge his authority in her communications with him made the difference. It is notable that in her correspondence with both Strehlow and Hasluck (although not with Mountford), she used her married name, Ruth Elizabeth Carell, which was unusual for her. Dean was no doubt in full realisation of the power these men wielded. She may well have deliberately downplayed her autonomy as a woman, as well as claiming to be only interested in female dance culture, to avoid any resistance by the authorities to her working too closely with Aboriginal men.

Even so, Dean was unable to secure the permission she needed to visit the reserves, nor was she able to secure funding. Instead the Carells returned to Australia in early 1952 on the strength of another tour of ethnic dance performance, mostly in New Zealand. It was at one performance in Sydney, apparently, when Dorothy Helmrich of the NSW Australian Arts Council invited Dean to choreograph a new version of Corroboree for the Queen's visit. ${ }^{60}$ This was the break Dean needed. The Carells finally received their official permits from the

55 Barry Hill, Broken Song: T. G. H. Strehlow and Aboriginal Possession (Sydney: Vintage, 2003), 338.

56 Julie Marcus, 'The Beauty, Simplicity and Honour of Truth: Olive Pink in the 1940s', in First in their

Field: Women and Australian anthropology, ed. Julie Marcus (Melbourne: Melbourne University Press, 1993),

128-30; Hill, Broken Song, 337-9.

57 Hill, Broken Song, 338.

58 T. G. H. Strehlow to Mrs Carell, 24 September 1952, Dean Papers ML MSS 7804/24.

59 Draft letter, Beth Dean to Paul Hasluck (n.d., c. 24 September 1952), Dean Papers ML MSS 7804/24.

60 De Berg Interview. 
Commonwealth authorities 'to enter and be upon' Aboriginal reserves in July $1953,{ }^{61}$ and set off in a sponsored Holden utility truck soon afterwards. ${ }^{62}$ They were in possession of a wire recorder, courtesy of the Wenner-Gren Foundation of New York, ${ }^{63}$ and a Kodak $16 \mathrm{~mm}$ film camera that they would use to make a promotion film of their journeys, Carrumbo. ${ }^{64}$

Notwithstanding her plans for the reworking of Corroboree, Dean did in fact carry out a great deal of research into Aboriginal women's dance culture. Her focus was not only to mollify the white anthropological establishment, nor satisfy her own curiosity, but was predicated on the limitations placed on her by the Aboriginal people she encountered. Evidence from her research notebooks clearly shows that her husband alone observed and made notes on men-only dances, then described to her the steps performed, with Dean restricted from attending these particular ceremonies. Clearly, she was positioned in the audience herself, by the Aboriginal people, as a woman.

In the published book this fact was something that had to be negotiated carefully. An episode at an initiation ceremony where all the women, Dean included, fled from the ground at the sound of the bullroarer, ${ }^{65}$ was reworked with some poetic license so as to have occurred at an earlier part of the ceremony. Here, having implied that she had only joined the women's departure because the panic had alarmed her (rather than because she was obliged to), the incident was used as a device to indicate Dean's difference from Aboriginal women: 'It was obvious that centuries of taboo were too deeply ingrained in the lubra soul for the women ever to disobey the rule not to disturb "blackfellow business". ${ }^{66}$ No mention was made of Dean having covered her eyes during the lead-up (the 'women covered their eyes at specific moments in the ceremony-as I myself did with my notebooks', she had written in her notes), nor of the two boy 'escorts' who held her hands and ensured that she did leave when required ${ }^{67}$

These young boys played another, inverted role in the book, as pre-initiates from whom she, as the knowledgeable observer, withheld taboo knowledge. As Dean was writing in her notebooks, she found 'Gordon, her shadow, was at her elbow, spelling out words', and 'since so much of her notes was of things taboo to uninitiated boys, she changed into French, which intrigued and mystified

61 'Permit to Enter and Be Upon an Aboriginal Reserve', stamped 14 July 1953, Dean Papers ML MSS 7804/24. 62 Dean and Carell, Dust for the Dancers, 5; Beth Dean and Victor Carell, Twin Journey: To Sing, To Dance, To Live (Sydney: Pacific Publications, 1983), 152-3; Victoria Haskins, 'The Smoking Buggy', in Off the Beaten Track: A journey across the nation, ed. Allison Russell (Birdwood: National Motor Museum, 2008), 76-7.

63 Mountford to Carells, 2 February 1953, notations by Dean dated April 1999, Dean Papers MLMSS $7804 / 24$.

64 Beth Dean, Victor Carell and Roland Litchfield, Carrumbo; 'to take a long journey', motion picture, General Motors-Holden Ltd, n.d., c. 1954. Copy available at Mitchell Library, Sydney.

65 'An experience at an initiation ceremony ... Beth Dean', Dean Papers ML MSS 7804/34.

66 Dean and Carell, Dust for the Dancers, 173-4.

67 An experience at an initiation ceremony ... Beth Dean', Dean Papers ML MSS 7804/34. 
him'. Trying unsuccessfully to keep him and his friend Charlie from catching a 'glimpse of a rough sketch of a tjurunga' (a sacred object owned by an initiated man, not to be seen by non-initiates), she was obliged to close the book altogether: Again Beth felt the sense of having no hiding place. ${ }^{68}$ While there are indeed pages written in 'schoolgirl French' (although no accompanying sketch of a tjuringa) amongst Dean's papers, alongside these notes she provided the information that she had as her constant 'companions' two daughters of one of the senior elders, who explained 'what to do at strategic moments' in the ceremonies. ${ }^{69}$ In using such a semi-fictional and transgressive anecdote to place herself in a position of knowledge and authority over uninitiated youths in her published account, Dean again sought to distance herself from the gender constraints imposed by her Aboriginal hosts.

She also, significantly, sought to distance herself from the gender constraints upon white women in central and northern Australia. Typically, it was white women who acted as the conduit enabling Dean to meet local Aboriginal women and view their performances. At Mt Doreen station in central Australia, for instance, the owner's wife announced she had a 'surprise' for her guests, following dinner. She led the party around 'the back of the sheds' to find 'all the camp girls' waiting beside their small camp fires to perform a special series of women's dances. Dean reported that the 'dancing women,' painted in black and white designs, demonstrated 'a complete series of secret Yowulyu "women business" dances' for their audience. Dean was convinced that the stationowner's wife, Doreen Braitling, was oblivious to their real meaning:

The large number of stanzas, sixty-nine in all, told in delicate stylization the full story of lovemaking-gradually evolving it from the first tentative manner of womenkind, to coitus and its resulting languor. All was done symbolically, beautifully, modestly, so much so, that we felt sure that Mrs. Braitling had very little idea of what the girls were telling, with their often gracious, sometimes oddly tense dance movements.

These dances are so stylistic in arrangement, that the station women everywhere who have seen them are seldom aware of their actual significance and deeply psychological origins. They find them lovely and charming to watch, even as we did. ${ }^{70}$

68 Dean and Carell, Dust for the Dancers, 168

69 Red exercise book, 'Strehlow - Ayers Rock Rain Luritja Dance - Raelene', Dean Papers ML MSS $7804 / 33$

70 Dean and Carell, Dust for the Dancers, 140-1. 
Despite Dean's dependence on women like Doreen Braitling, the portrait presented cemented the difference of 'station women' not only from Aboriginal women but also from the world-travelling dance scholar and ethnologist Beth Dean.

Mrs Braitling is a charming, capable and sincere woman, who has lived most of her life in this secluded spot with only her husband, her son and the tribe of blacks. Her days are busy, and she works hard at her responsibility of feeding her "family" - for the blacks are dependent on the station homestead for much of their food. Each day she bakes at least sixty large loaves of snowy white bread. All water must be brought to the house in forty-four gallon drums from a small creek a few miles away. With all her busy life, Mrs. Braitling has still found time to be not only interested in but sympathetic toward her aborigines. ${ }^{71}$

As evidence for this, Braitling showed her visitors her personal collection of Aboriginal artefacts, including a tjuringa that her husband had reportedly been given by one of the Aboriginal men. In truth, Dean also depended on her husband to access and display Aboriginal men's culture. But in asserting her understanding of Aboriginal women's sexuality in contrast to her hostess' ignorance, Dean made a powerful, and profoundly gendered, claim for authority.

Were the white men of the party in the audience for these women's dances? As with the other accounts of watching women's dancing in Dust for the Dancers, a blurring of masculine and feminine viewpoint made it impossible for the reader to discern when Dean or her husband was the witness. But throughout the book a framing white male gaze was adopted, authority derived from male anthropological knowledge and proven by a frank recognition (and appreciation) of Aboriginal female sexuality. The most powerful statement of the book's perspective resides in the startling voyeuristic images of nubile and naked young girls that appear throughout the book. ${ }^{72}$ The message is clear here: the white audience for Aboriginal women was male.

It is possible that Mrs Braitling actually knew more about Aboriginal women and sex than did her guests. Back in 1940, Strehlow had inspected the Braitlings' property, in his capacity as an Aboriginal Patrol Officer, and found that over half of the thirty-three adults tested at the Aboriginal camp had venereal disease (gonorrhoea). There was, Strehlow felt, a very 'low morale of the native community here' in contrast to 'other groups' ${ }^{73}$ Two years later, another patrol officer visiting the station found the children and women there to be 'all naked and in a "deplorable condition"":

71 Dean and Carell, Dust for the Dancers, 140.

72 Dean and Carell, Dust for the Dancers, 56, 101, 127, 128, 179.

73 Hill, Broken Song, 339. 
The semi-starvation in which they wage their constant battle against a hostile milieu was apparent in their thin limbs and haggard faces. A constant chorus of coughing, spitting and the crying of hungry children arose. My cook worked half the night making johnny cakes from our slender stock, and we did what we could for them. ${ }^{74}$

In light of these two horrific reports, Dean's observations a decade later about Mrs Braitling's 'busy' days baking bread for her Aboriginal 'family' and her inability to recognise the sexuality of the Aboriginal women have a peculiarly macabre ring. White women like Olive Pink were denied the gaze of the colonising white man precisely because of what they might see from that perspective: white male violence against Aboriginal people, sexual and otherwise. ${ }^{75}$ But Beth Dean never offered any such challenge to white patriarchal authority. Instead, she allied herself with the white man in her complacent description of Aboriginal women's sexuality: 'sex is as ordinary a part of normal life to the natives as thirst and hunger' ${ }^{76}$

In some ways, however, Dean's interest in Aboriginal women's dances and the gender divisions in Aboriginal dance culture can be read as a challenge to the very patriarchal attitudes that dominated anthropology, and indeed the wider white Australian society, at the time. She was careful to identify which dances were women's and which were men's dances, her notes scattered with comments such as: 'MATARANKA Buffalo Dance-Women only Dance-Men only may sing-Very strict on this' ${ }^{77}$ She was clearly irritated by the common assumption that Aboriginal women didn't perform 'corroboree', ${ }^{78}$ making sure some women's dances were included in the ballet. Like Margaret McArthur, the nutritionist on Mountford's 1948 expedition, Dean seems to have celebrated the existence of women's dances as evidence of Aboriginal women's wellbeing and empowerment. ${ }^{79}$

A review of the ballet sent to her before publication stated, mistakenly, that as women were 'traditionally kept away from significant ceremonies', Dean's female dancers were actually impersonating males. This drew from her the terse

\footnotetext{
74 Quoted in Hill, Broken Song, 366-7.

75 Marilyn Lake, 'Frontier Feminism and the Marauding White Man', Journal of Australian Studies: Australian Frontiers 49 (1996): 12-20.

76 Dean and Carell, Dust for the Dancers, 140-1.

77 'Notes on a Table Listing Different Dances', Dean Papers ML MSS 7804/34.

78 Her attempts to refute this belief recur in her book, Beth Dean, The Many Worlds of Dance (Sydney: K.

G. Murray, 1966), 39, and in her public talks: Dean Papers ML MSS 7804/8.

79 See also Harris, this volume.
} 
response: 'note: women do appear. Beth Dean' ${ }^{80}$ After Dean's intervention, the reviewer eventually published an article in which he made more of the taboos she and her husband had been able to evade, instead:

Some of the secret and sacred dances of the initiation ceremonies, which are strictly taboo for women, were taken down by Mr Carell, whereas Beth Dean was admitted to the exclusive women's dances. As so far most explorers and ethnologists had been men, the existence of many of these dances had not even been suspected. Elated with the result of their work, having gathered fresh material which was "good theatre", the two returned to civilisation. ${ }^{81}$

Of course, the 'taboos' around male performance were those that most titillated the white audiences and would give a particular frisson to Dean's performance as a male initiate.

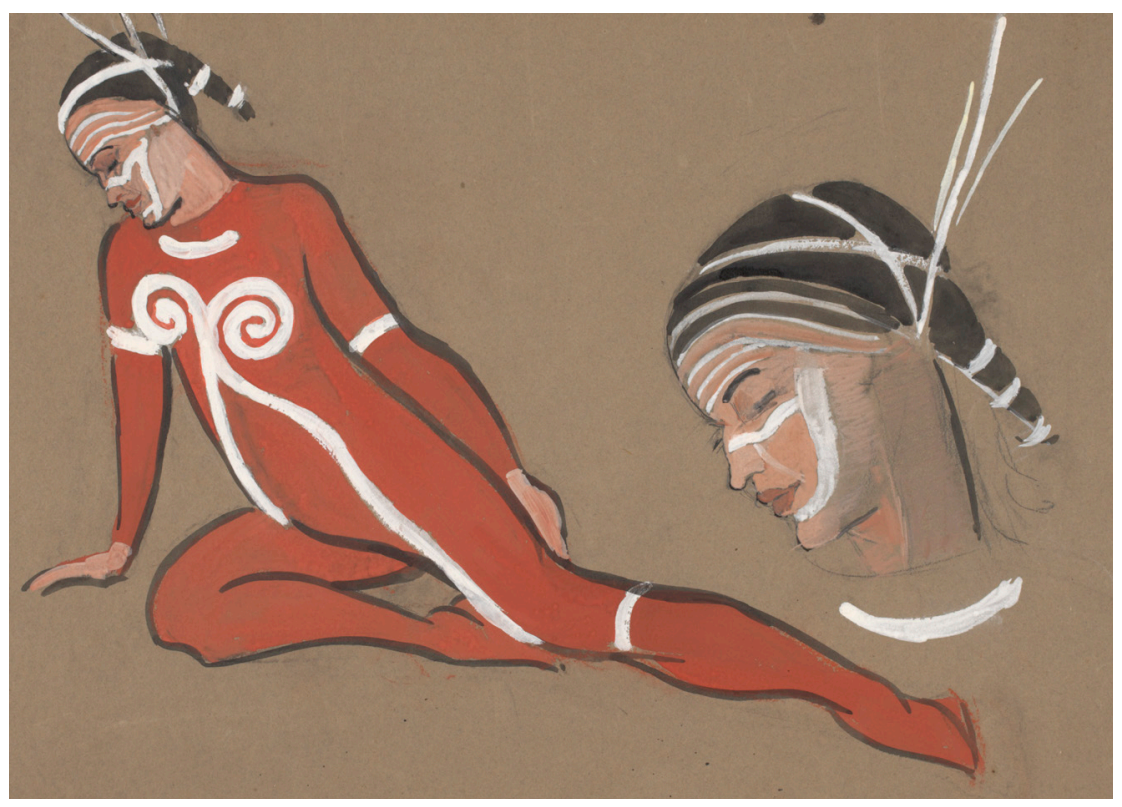

Figure 3: A sketch of Beth Dean in costume for the ballet Corroboree, dated 1950. William Constable, 1906 Bendigo, Victoria-1989 Melbourne, Victoria. Drawing, pencil, ink and goache on cream paper, $38.7 \mathrm{~cm} \mathrm{~h} \mathrm{x} 53 \mathrm{~cm} \mathrm{w}$.

Source: National Museum of Australia Collection (1997.0047.0062).

80 'Typed Copy of an Article (or Radio Transcript?) by Cornelius Coyne 2BL 12 Feb 10pm, Beth Dean's Notation', Dean Papers ML MSS 7804/8.

81 Cornelius Coyne, 'Corroboree into Ballet', The Weekly News (New Zealand), 2 June 1954, clipping, Dean Papers ML MSS 7804/8. 


\section{Conclusion}

Beth Dean was in a paradoxical position - and not only when she donned the brown tights and pancake make-up to impersonate a male initiate. An emancipated modern woman transcending not only national borders but the boundaries of race and gender, she remained critically dependent upon the support, and indeed endorsement, of the white male expert to achieve her aims. As a representative of a white female audience, Dean vicariously allowed white women to feel that they too could breach the barriers that were 'too deeply ingrained in the lubra soul', and enter into a field of knowledge and power hitherto dominated by white male anthropologists. But whereas the implication was that Dean had transcended these barriers in central Australia, as in the ballet, in fact, she had not.

In the recurrent narrative describing her life's journey Dean chose to allocate a symbolically powerful role to Charles Pearcy Mountford as her inspiration and catalyst. Undoubtedly the meeting between Mountford and the young couple in New York was pivotal for Dean, yet she was just one of many keen and enthusiastic women of her time, seeking benediction for her project. Mountford himself would probably have forgotten her had she not had the determination to persist and to bind his authority to him as tightly as she could. For Dean, Mountford was a kind of elder, conferring the wisdom and status of the white male anthropologist upon her. Dean described her ballet as 'a hymn of praise for Aboriginal traditional life', ${ }^{82}$ but the gender and racial transgression she performed in Corroboree in many ways represented rather a tribute to the authority of the white male expert, and a quest to replicate his experiences.

And yet at the same time Dean - whether she realised or acknowledged the fact - was part of a longer tradition of white women contesting male authority indirectly through representing and producing cross-cultural knowledges. Her success was in large part due not to the authority that her association with Mountford invested, but to the nature of her times, when efforts by newly privileged white women like herself, to assert their ability to transcend once immutable barriers, met with acclaim and delight. In Dust for the Dancers, the initiation ceremonies were described as 'an expression of the utmost feeling and purpose' that would enable 'the boy [to] take his place among the men of the tribe ... not going, as before, only with the women. During the ceremonials he would take his place as a man. ${ }^{83}$ So too, we might venture, did Beth Dean take her place.

82 'Notes on the ballet CORROBOREE', c. 1954, Letters and notes related to Beth Dean Carell's ballet career, Beth Dean Carell Collection no. 1, National Museum of Australia, Canberra.

83 Dean and Carell, Dust for the Dancers, 184. 


\section{Acknowledgements}

The original research for this study was carried out under the auspices of a Council of Australian State Libraries Fellowship in 2006-2007 and supported by an internal grant from the University of Newcastle. I would also like to acknowledge the input and advice of colleagues at the University of Sydney's PARADISEC Sydney Seminar Series in 2011, especially that of Martin Thomas, and the generosity of the William Constable estate, the National Museum of Australia, and the State Library of NSW, in allowing the images herein to be reproduced.

\section{References}

Anderson, Jim. "A glorious thing is to live in a tent in the infinite": Daisy Bates', in Uncommon Ground: White women in Aboriginal history, eds Anna Cole, Victoria Haskins and Fiona Paisley (Canberra: Aboriginal Studies Press, 2005), 217-31

Bruce, Candice and Anita Callaway. 'Wild Nights and Savage Festivities: White views of corroborees', Art and Australia 27:2 (1989), 269-75.

Bruce, Candice and Anita Callaway. 'Dancing in the Dark: Black corroboree or white spectacle?', Australian Journal of Art 9 (1991): 79-104.

Buller-Murphy, Deborah. An Attempt to Eat the Moon and Other Stories Recounted from the Aborigines (Melbourne: Georgian House, 1958).

Burridge, Stephanie. The Impact of Aboriginal Dance on Twentieth Century Australian Choreography with a Practical and Creative Study (PhD, London Contemporary Dance School at The Place, University of Kent at Canterbury, 1997).

Card, Amanda. "From "Aboriginal Dance" to Aboriginals Dancing: The appropriation of the "primitive" in Australian dance', in Speaking of History: Dance scholarship in the '90s: Proceedings of Society of Dance Scholars Nineteenth Annual Conference (Minnesota: University of Minnesota, 1996), 115-26.

Card, Amanda. "From "Aboriginal Dance" to Aboriginals Dancing: The appropriation of the "primitive" in Australian Dance, 1950 to 1963", in Heritage and Heresy: Green Mill Papers 1997 (Canberra: Australian Dance Council, 1998), 40-6. 
Card, Amanda and Carole Y. Johnson. 'Aboriginal Influences', in Currency Companion to Music \& Dance in Australia, eds John Whiteoak and Aline Scott-Maxwell (Sydney: Currency House, 2003), 20-3.

Cooke, Glenn R. 'Aboriginal Motifs in the Decorative Arts, “an art for Australia from Australians"', in Motif and Meaning: Aboriginal influences in Australian art 1930-1970, ed. Claire Baddley (Ballarat: Ballarat Fine Art Gallery, 1999), 9-16.

Cubillo, Franchesca. 'I drew very close to these men, sharing their dilemma ...: Elizabeth Durack', in Uncommon Ground: White women in Aboriginal history, eds Anna Cole, Victoria Haskins and Fiona Paisley (Canberra: Aboriginal Studies Press, 2005), 232-40.

Dean, Beth. The Many Worlds of Dance (Sydney: K. G. Murray, 1966).

Dean, Beth and Victor Carell. Dust for the Dancers (Sydney: Ure Smith, 1955).

Dean, Beth and Victor Carell. Twin Journey: To sing, to dance, to live (Sydney: Pacific Publications, 1983).

Durack, Mary and Elizabeth Durack. All-About: The story of a black community on Argyle Station, Kimberley (Sydney: The Bulletin, 1935).

Ewers, John K. With the Sun on My Back (Sydney: Angus \& Robertson, 1953).

Fitzgerald, Mary A. King Bungaree's Pyalla and Stories Illustrative of Manners and Customs that Prevailed Among Australian Aborigines (Sydney: William Brooks \& Co, 1891).

Haebich, Anna. 'Assimilation and Hybrid Art: Reflections on the politics of Aboriginal art', in The Art of Politics The Politics of Art: The place of contemporary Indigenous art, ed. Fiona Foley (Southport: Keeaira Press, 2006).

Haebich, Anna. Spinning the Dream: Assimilation in Australia 1950-1970 (Fremantle: Fremantle Press, 2008).

Haebich, Anna and Jodie Taylor. 'Modern Primitives Leaping and Stomping the Earth: From ballet to bush doofs', Aboriginal History 31 (2007): 63-84.

Hammergren, Lena. 'Many Sources, Many Voices', in Rethinking Dance History: A reader, ed. Alexandra Carter (London: Routledge, 2004), 20-31.

Haskins, Victoria. 'Dancing in the Dust: A gendered history of indigenising Australian cultural identity', in Intersections: Gender, race and ethnicity in Australasian studies, eds Margaret Allen and R K Dhawan (New Delhi: Prestige, 2007), 55-75. 
Haskins, Victoria. 'The Smoking Buggy', in Off the Beaten Track: A journey across the nation, ed. Allison Russell (Birdwood: National Motor Museum, 2008), 72-81.

Haskins, Victoria. 'To Touch the Infinity of a Far Horizon: A transnational history of transcultural appropriation in Beth Dean's Corroboree 1954', Australasian Drama Studies 59 (2011): 23-38.

Hill, Barry. Broken Song: T. G. H. Strehlow and Aboriginal possession (Sydney: Vintage, 2003).

Holmes, Robyn. 'Australian Music Editing and Authenticity: "Would the real Mrs Monk please stand up?"', in The Editorial Gaze: Mediating texts in literature and the arts, eds Paul Eggert and Margaret Sankey (Oxon: Routledge, 2013), 209-26.

Jordan, Caroline. Picturesque Pursuits: Colonial women artists and the amateur tradition (Melbourne: Melbourne University Press, 2005).

Kociumbas, Jan. 'Performances: Indigenisation and postcolonial culture', in Cultural History in Australia, eds Hsu-Ming Teo and Richard White (Sydney: UNSW Press, 2003), 127-41.

Lake, Marilyn. 'Feminist History as National History: Writing the political history of women', Australian Historical Studies 27:106 (1996): 154-69.

Lake, Marilyn. 'Frontier Feminism and the Marauding White Man', Journal of Australian Studies: Australian Frontiers 49 (1996): 12-20.

Lawson, Valerie. 'Dancer Many Steps Ahead of Her Time: Beth Dean Carell 1918-2012', Sydney Morning Herald, 12 May 2012.

Marcus, Julie. 'The Beauty, Simplicity and Honour of Truth: Olive Pink in the 1940s', in First in their Field: Women and Australian anthropology, ed. Julie Marcus (Melbourne: Melbourne University Press, 1993), 111-35.

Maynard, John. 'Light in the Darkness: Elizabeth McKenzie-Hatton', in Uncommon Ground: White women in Aboriginal history, eds Anna Cole, Victoria Haskins and Fiona Paisley (Canberra: Aboriginal Studies Press, 2005), 3-27.

McGregor, Russell. Imagined Destinies: Aboriginal Australians and the doomed race theory, 1880-1939 (Melbourne: Melbourne University Press, 1997).

McGuire, Madeline E. 'The Legend of the Good Fella Missus', Aboriginal History 14:2 (1990): 135-9. 
Merlan, Francesca. 'Gender in Aboriginal Social Life: A review', in Social Anthropology and Australian Aboriginal Studies, eds R M Berndt and R Tonkinson (Canberra: Australian Institute of Aboriginal Studies, 1988), 19 45.

Niall, Brenda. Seven Little Billabongs: The world of Ethel Turner and Mary Grant Bruce (Melbourne: Melbourne University Press, 1979).

Niall, Brenda. True North: The story of Mary and Elizabeth Durack (Melbourne: Text Publishing, 2012).

Parker, K. Langloh. Australian Legendary Tales (Middlesex: Tiger Books, 1998).

Pask, Edward H. Ballet in Australia: The second act 1940-1980 (Melbourne: Oxford University Press, 1982).

Patten, J. T. and W. Ferguson, Aborigines Claim Citizen Rights! (Sydney: The Publicist, 1938).

Potter, Michelle. 'Making Australian Dance: Themes and variations', Voices (1996): 10-20.

Riddett, Lyn A. “'Be Aboriginal”: Settler women artists inspired by Aboriginal artists', Northern Perspective 19:1 (1996): 51-60.

Rowley, C. D. The Destruction of Aboriginal Society (Ringwood: Penguin, 1986).

Russell, Penny. 'Cultures of Distinction', in Cultural History in Australia, eds Hsu-Ming Teo and Richard White (Sydney: UNSW Press, 2003), 158-71

Sayers, Andrew. Aboriginal Artists of the Nineteenth Century (Melbourne: Oxford University Press, 1994).

Stone, Walter W., ed. Charles Pearcy Mountford: An annotated bibliography (Cremorne: The Stone Copying Company, 1958).

Thomas, Martin. 'A Short History of the 1948 Arnhem Land Expedition', Aboriginal History 34 (2010): 143-70.

Thomson, John. 'It's Australian - and it's good!' National Library of Australia News 14:3 (2003), http://www.australianmusicals.com/article_itsaustralian. htm.

Unattributed biography. 'Dean, Beth (1918-2012)', Australia Dancing, accessed 14 March 2012, http://www.australiadancing.org/subjects/26.html.

Vignando, Catrina. 'Corroboree: Aboriginal inspiration in contemporary Australian ballet,' Olive Pink Society Bulletin 3:2 (1991): 10-14. 
W., M. H. 'Queen Rosie's Requiem', Sydney Morning Herald, 21 June 1932.

West, J., ed. Collits' Inn: A romantic Australian operetta by T Stuart Gurr with lyrics and music by Varney Monk (Sydney: Currency Press, 1990).

Young, John Atherton, ed. Jane Bardsley's Outback Letterbook, Across the Years 1896-1936 (Sydney: Angus \& Robertson, 1987). 
This text taken from Circulating Cultures: Exchanges of Australian Indigenous music, dance and media, edited by Amanda Harris, published 2014 by ANU Press, The Australian National University, Canberra, Australia. 